\title{
Influence of Physical and Chemical Parameters on the Treatment of Heavy Metals in Polluted Stormwater Using Zeolite-A Review
}

\author{
Abdul M. Ziyath ${ }^{1}$, Parvez Mahbub ${ }^{1 *}$, Ashantha Goonetilleke ${ }^{1}$, Moses O. Adebajo ${ }^{2}$, \\ Serge Kokot ${ }^{2}$, Adekunle Oloyede ${ }^{3}$ \\ ${ }^{1}$ School of Urban Development, Queensland University of Technology, Brisbane, Australia \\ ${ }^{2}$ Chemistry Discipline, Queensland University of Technology, Brisbane, Australia \\ ${ }^{3}$ School of Engineering Systems, Queensland University of Technology, Brisbane, Australia \\ E-mail: \{mohamed.ziyath, 's.mahbub, a.goonetilleke, m.adebajo, s.kokot, k.oloyede\}@qut.edu.au \\ Received July 17, 2011; revised August 23, 2011; accepted September 26, 2011
}

\begin{abstract}
Zeolite-based technology can provide a cost effective solution for stormwater treatment for the removal of toxic heavy metals under increasing demand of safe water from alternative sources. This paper reviews the currently available knowledge relating to the effect of properties of zeolites such as pore size, surface area and $\mathrm{Si}: \mathrm{Al}$ ratio and the physico-chemical conditions of the system such as $\mathrm{pH}$, temperature, initial metal concentration and zeolite concentration on heavy metal removal performance. The primary aims are, to consolidate available knowledge and identify knowledge gaps. It was established that an in-depth understanding of operational issues such as, diffusion of metal ions into the zeolite pore structure, pore clogging, zeolite surface coverage by particulates in stormwater as well as the effect of $\mathrm{pH}$ on stormwater quality in the presence of zeolites is essential for developing a zeolite-based technology for the treatment of polluted stormwater. The optimum zeolite concentration to treat typical volumes of stormwater and initial heavy metal concentrations in stormwater should also be considered as operational issues in this regard. Additionally, leaching of aluminium and sodium ions from the zeolite structure to solution were identified as key issues requiring further research in the effort to develop cost effective solutions for the removal of heavy metals from stormwater.
\end{abstract}

Keywords: Zeolite, Heavy Metals, Stormwater, Leaching, Stormwater Reuse

\section{Introduction}

Access to safe drinking water has been declared as a basic human right by the United Nations [1]. Some 884 million people do not have access to safe water due to the pollution of conventional water sources [2]. Additionally, rapid population growth and increased urbanisation have resulted in an unprecedented demand for both potable and non-potable water. In recent years, intensive efforts have been focused on utilising largely unused stormwater as an alternative water source as it is generally available in large volumes and easily accessible [3-5]. However, stormwater can contain harmful pollutants such as heavy metals, hydrocarbons and pathogens when collected from various land surfaces [6,7]. Thus, a significant level of treatment is required before reuse.
Numerous research studies have investigated the treatment of these pollutants [8-13].

Among stormwater pollutants, heavy metals are of particular interest due to their toxicity and persistence in the environment [14-16]. They can cause health problems in humans and animals ranging from irritation to cancers [17-19]. Several physico-chemical techniques, such as the use of detention ponds, coagulation-flocculation and chemical precipitation have been investigated for the removal of heavy metals [20-24]. However, most of these techniques have economical and environmental consequences such as generation of contaminated sludge and high capital and operational costs $[25,26]$. Consequently, research efforts have been directed towards adsorption using low cost sorbents such as peat moss, clays and zeolites as an alternative technique for the removal 
of heavy metals in stormwater due to their economical and environmental benefits.

Zeolites could provide a low cost solution, as these materials are generally less expensive compared to commercial sorbents such as activated carbon and can remove a number of harmful pollutants, including toxic heavy metals [27]. The performance of zeolites in the removal of heavy metals has been widely discussed in research literature and conclusions vary widely in relation to their treatment performance $[28,29]$. This can be primarily attributed to the differing experimental conditions and the properties of zeolite used in these studies. This emphasises the fact that an in-depth knowledge on the influence of physical and chemical factors on the performance of zeolite is essential for the development of approaches for the removal of heavy metals from polluted stormwater. In this context, a comprehensive stateof-the-art review of research literature was undertaken with the aim of consolidating currently available knowledge and to obtain a fundamental understanding regarding the influence of physical and chemical parameters on the heavy metal removal performance of zeolites. The objective of this review encompasses evaluating available zeolite-based approaches targeting removal of heavy metals from stormwater, currently available knowledge as well as to identifying any knowledge gaps that need to be addressed. Furthermore, with the view to highlighting the key issues in removing heavy metals from stormwater, the structure of zeolite and the influence of the properties of zeolite and experimental conditions are discussed.

\section{Structure of Zeolite}

A fundamental knowledge on the structure of zeolite is essential to better understand the effects of physico-chemical properties of zeolite and experimental conditions on heavy metal removal performance. Zeolite is an aluminosilicate porous material built on a three-dimensional network of $\mathrm{SiO}_{4}$ or $\mathrm{AlO}_{4}$ tetrahedral structures as illustrated in Figure 1 [30].

Various secondary structures such as cages and cavities are also found in zeolite due to different arrangement of the tetrahedral structures. The porous nature of zeolite is a result of these secondary structures.

The presence of trivalent $\mathrm{Al}$ atoms in the framework results in an anionic framework, which is neutralised by the extra framework cations such as sodium $\left(\mathrm{Na}^{+}\right)$, calcium $\left(\mathrm{Ca}^{2+}\right)$ and magnesium $\left(\mathrm{Mg}^{2+}\right)$ [31]. Heavy metal cations in solution can be exchanged for these extra framework cations via ion exchange mechanism, which is, in certain cases, found to be the primary mechanism of heavy metal sorption employed by zeolite [32-34].

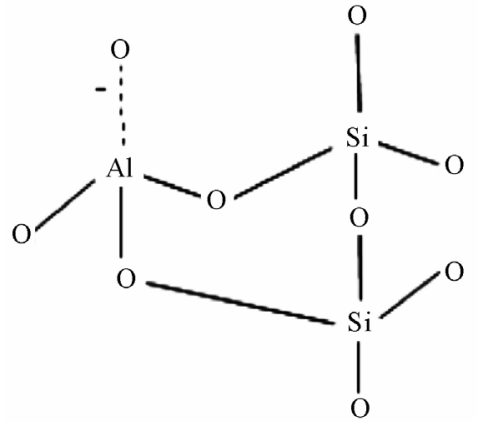

Figure 1. Tetrahedral structure of zeolite.

However, other mechanisms such as physisorption and chemisorption are also employed by zeolites for the sorption $[35,36]$.

\section{Sorption of Heavy Metals by Zeolite}

Table 1 outlines the sorption capacities and selectivity series reported in research studies in order to highlight the different conclusions drawn by different studies. As evident in Table 1, the primary reason for the different selectivity series and sorption capacities is the use of different zeolite species. For example, in the study by Ouki and Kavannagh [32], two zeolite species, namely, clinoptilolite and chabazite were tested under the same experimental conditions and different selectivity series and sorption capacities were reported (Table 1). The main properties of zeolite that influence heavy metal removal performance are aluminium content or $\mathrm{Si}: \mathrm{Al}$ ratio, pore size and surface area. On the other hand, the sorption capacities and selectivity series reported for clinoptilolite in different studies are different as shown in Table 1. Though, there can be some variations in the chemical composition of clinoptilolite due to their source of origin, the physical and chemical conditions used in each experiment were clearly different. Temperature, $\mathrm{pH}$, zeolite concentration and initial metal concentration are the major parameters that are considered to have an effect on the removal of heavy metals.

\subsection{Influential Zeolite Properties}

\subsubsection{Si:Al Ratio}

$\mathrm{Si}: \mathrm{Al}$ ratio indicates the amount of $\mathrm{Al}$ atoms present in the zeolite framework. As discussed in Section 2, the presence of more $\mathrm{Al}$ results in more negative charges in the zeolite structure. Thus, zeolite with low Si:Al ratio, i.e. high $\mathrm{Al}$ content, contains more binding sites and there are extra framework cations in its structure. In theory, therefore, zeolite with low Si:Al ratio has high sorption capacity compared to zeolite with high Si:Al ratio. 
Table 1. Sorption capacities and selectivity for heavy metals for selected zeolites.

\begin{tabular}{|c|c|c|c|c|}
\hline Zeolite & $\mathrm{SC}^{\mathrm{a}} /(\mathrm{mg} / \mathrm{g})$ & Selectivity series & Experimental conditions & References \\
\hline \multirow{3}{*}{ Clinoptilolite } & $\begin{array}{c}2.4(\mathrm{Cr}), 1.5(\mathrm{Co}), 0.9(\mathrm{Ni}), 3.8(\mathrm{Cu}) \\
2.7(\mathrm{Zn}), 3.7(\mathrm{Cd}), 6.0(\mathrm{~Pb})\end{array}$ & $\mathrm{Pb}^{2+}>\mathrm{Cu}^{2+}>\mathrm{Cd}^{2+}>\mathrm{Zn}^{2+}>\mathrm{Cr}^{3+}>\mathrm{Co}^{2+}>\mathrm{Ni}^{2+}$ & $\begin{array}{l}\mathrm{IMC}^{\mathrm{b}}(1-30 \mathrm{mg} / \mathrm{L}) \\
\mathrm{pH}(3-6), \mathrm{ZC}^{\mathrm{c}}(5 \mathrm{~g} / \mathrm{L})\end{array}$ & {$[32]$} \\
\hline & $101(\mathrm{~Pb}), 11.7(\mathrm{Cu}), 6.8(\mathrm{Cr}), 5.58(\mathrm{Fe})$ & $\mathrm{Pb}^{2+}>\mathrm{Cr}^{3+}>\mathrm{Fe}^{3+}>\mathrm{Cu}^{2+}$ & $\begin{array}{c}\mathrm{IMC}(10 \mathrm{mg} / \mathrm{L}) \\
\mathrm{ZC}(0.5-180 \mathrm{~g} / \mathrm{L}), \mathrm{pH}(2-4)\end{array}$ & {$[37]$} \\
\hline & $\begin{array}{c}5.91(\mathrm{Cu}), 4.12(\mathrm{Cr}), 3.45(\mathrm{Zn}) \\
1.98(\mathrm{Ni}), 4.60(\mathrm{Cd})\end{array}$ & $\mathrm{Cu}^{2+}>\mathrm{Cr}^{3+}>\mathrm{Zn}^{2+}>\mathrm{Cd}^{2+}>\mathrm{Ni}^{2+}$ & $\begin{array}{c}\mathrm{IMC}(100 \mathrm{mg} / \mathrm{L}), \mathrm{pH}(3-6) \\
\mathrm{ZC}(2.5-5 \mathrm{~g} / \mathrm{L})\end{array}$ & {$[38]$} \\
\hline Chabazite & $\begin{array}{c}3.6(\mathrm{Cr}), 5.8(\mathrm{Co}), 4.5(\mathrm{Ni}), 5.1(\mathrm{Cu}) \\
5.5(\mathrm{Zn}), 6.7(\mathrm{Cd}), 6.0(\mathrm{~Pb})\end{array}$ & $\mathrm{Pb}^{2+}>\mathrm{Cd}^{2+}>\mathrm{Zn}^{2+}>\mathrm{Co}^{2+}>\mathrm{Cu}^{2+}>\mathrm{Ni}^{2+}>\mathrm{Cr}^{3+}$ & $\begin{array}{c}\operatorname{IMC}(1-30 \mathrm{mg} / \mathrm{L}), \mathrm{pH}(3-6), \\
\mathrm{ZC}(5 \mathrm{~g} / \mathrm{L})\end{array}$ & {$[32]$} \\
\hline Zeolite X & $549(\mathrm{~Pb}), 109(\mathrm{Cu}), 162(\mathrm{Cd}), 70(\mathrm{Ni})$ & $\mathrm{Pb}^{2+}>\mathrm{Cu}^{2+}>\mathrm{Cd}^{2+}>\mathrm{Ni}^{2+}$ & $\begin{array}{l}\text { IMC }(20-2000 \mathrm{mg} / \mathrm{L}) \\
\quad \text { ZC }(2 \mathrm{~g} / \mathrm{L})\end{array}$ & [39] \\
\hline Zeolite $13 \mathrm{X}$ & $136(\mathrm{Cu}), 100(\mathrm{Co}), 86.3(\mathrm{Ni})$ & $\mathrm{Cu}^{2+}>\mathrm{Co}^{2+}>\mathrm{Ni}^{2+}$ & $\begin{array}{l}\text { IMC }(1.5-3 \mathrm{mmol} / \mathrm{L}) \\
\mathrm{ZC}(20 \mathrm{~g} / \mathrm{L}), \mathrm{pH}(3.5)\end{array}$ & {$[40]$} \\
\hline Zeolite 4A & $\begin{array}{c}13.7(\mathrm{Co}), 41.6(\mathrm{Cr}), 50.5(\mathrm{Cu}) \\
9.0(\mathrm{Ni}), 30.8(\mathrm{Zn})\end{array}$ & $\mathrm{Cu}^{2+}>\mathrm{Cr}^{3+}>\mathrm{Zn}^{2+}>\mathrm{Co}^{2+}>\mathrm{Ni}^{2+}$ & $\begin{array}{l}\mathrm{IMC}(50-300 \mathrm{mg} / \mathrm{L}) \\
\quad \mathrm{ZC}(5 \mathrm{~g} / \mathrm{L}), \mathrm{pH}(3)\end{array}$ & {$[33]$} \\
\hline Zeolite NaP1 & $\begin{array}{c}43.6(\mathrm{Cr}), 20.1(\mathrm{Ni}), 32.6(\mathrm{Zn}) \\
50.5(\mathrm{Cu}), 50.8(\mathrm{Cd})\end{array}$ & $\mathrm{Cr}^{3+}>\mathrm{Cu}^{2+}>\mathrm{Zn}^{2+}>\mathrm{Cd}^{2+}>\mathrm{Ni}^{2+}$ & $\begin{array}{l}\mathrm{IMC}(100 \mathrm{mg} / \mathrm{L}), \mathrm{pH}(3-6) \\
\mathrm{ZC}(2.5-5 \mathrm{~g} / \mathrm{L})\end{array}$ & {$[38]$} \\
\hline
\end{tabular}

$\mathrm{SC}^{\mathrm{a}}$-Sorption capacities; IMC ${ }^{\mathrm{b}}$ - Initial metal concentration; $\mathrm{ZC}^{\mathrm{c}}$ - zeolite concentration.

Several studies report the superior heavy metal sorption capacities for zeolites with low Si:Al ratios [38,41-43].

The prominent role played by Si:Al ratio on the sorption of heavy metals has been demonstrated in the study of Leinonen and Lehto [42]. They investigated the uptake of $\mathrm{Zn}, \mathrm{Ni}, \mathrm{Cd}, \mathrm{Cu}$ and $\mathrm{Co}$ cations using zeolites having the same framework structure, but different $\mathrm{Si}: \mathrm{Al}$ ratios. The results showed that a higher amount of metal ions was generally sorbed by zeolite with lower Si:Al ratio. Panayotova [35] found that the uptake of $\mathrm{Cu}^{2+}$ from wastewater increased when zeolites were modified with $\mathrm{NaOH}$ and decreased when zeolites were treated with $\mathrm{HCl}$. This is because $\mathrm{NaOH}$ can dissolve $\mathrm{Si}$ atoms from zeolite framework, i.e. desilication, hence decreasing the $\mathrm{Si}: \mathrm{Al}$ ratio [44]. On the other hand, $\mathrm{HCl}$ is known to dissolve $\mathrm{Al}$ atoms from zeolite framework, i.e. dealumination, hence increasing the $\mathrm{Si}: \mathrm{Al}$ ratio [45].

The concentration of heavy metals in stormwater is generally low, typically in the range of $\mu \mathrm{g} / \mathrm{L}$ [46]. It could therefore be expected that zeolite with low Si:Al ratio may have an adequate amount of binding sites for the treatment of stormwater.

\subsubsection{Pore Size}

The active sites, to which heavy metals are bonded, can also be present inside the pores of zeolite. In such cases, a cation needs to diffuse inside the pores in order to be sorbed. However, a cation cannot enter into the porous structure if the ionic size is larger than that of the pore opening [33]. Even after entry, diffusion of the ion through the pores can be retarded if the internal dimensions of the porous structure are smaller than the ionic size.

Metal cations in aqueous solution are found in their hydrated forms, i.e. $\mathrm{M}\left(\mathrm{H}_{2} \mathrm{O}\right)_{\mathrm{n}}$. However, size of pore opening and/or the internal dimensions of the most common zeolite species are generally smaller than the hydrated ionic diameter of metals listed in Table 2 [47].

For example, the pore size of synthetic zeolite $4 \mathrm{~A}$ is $0.4 \mathrm{~nm}$, while clinoptilolite, which is the most common natural zeolite species, has three-dimensional channels with dimensions $(0.3 \mathrm{~nm} \times 0.76 \mathrm{~nm}),(0.33 \mathrm{~nm} \times 0.46$ $\mathrm{nm})$ and $(0.26 \mathrm{~nm} \times 0.47 \mathrm{~nm})$ [47]. Therefore, hydrated heavy metal cations must lose some of their water molecules to reduce their ionic size in order to enter into the porous structure of zeolites [38].

Many research studies have noted the difficulty in the

Table 2. Hydrated ionic diameters of heavy metals ${ }^{1}$ (adapted from Nightingale [48]).

\begin{tabular}{cc}
\hline Metal ion & Hydrated ionic diameter (nm) \\
\hline $\mathrm{Pb}^{2+}$ & 0.802 \\
$\mathrm{Cd}^{2+}$ & 0.852 \\
$\mathrm{Cu}^{2+}$ & 0.838 \\
$\mathrm{Cr}^{3+}$ & 0.922 \\
$\mathrm{Ni}^{2+}$ & 0.808 \\
$\mathrm{Zn}^{2+}$ & 0.860 \\
$\mathrm{Al}^{3+}$ & 0.950
\end{tabular}

${ }^{1}$ Heavy metals commonly found in stormwater have been listed. 
diffusion of large hydrated ions into small pores as a reason for the low sorption of certain heavy metal cations $[32,41,49]$. For example, El-Kamash et al. [49] observed that the sorption capacity of zeolite increased with increasing temperature. They concluded that this may be due to the increased diffusion of heavy metal ions into zeolite pores as a consequence of heavy metal cations losing some of their water molecules at high temperature. Furthermore, Chang and Shih [41] stated that the sorption of caesium cation $\left(\mathrm{Cs}^{+}\right)$by synthetic zeolite $\mathrm{X}$ is higher than by synthetic zeolite A. However, as synthetic zeolite $\mathrm{A}$ has a lower $\mathrm{Si}$ :Al ratio than that of synthetic zeolite $\mathrm{X}$ it is contrary to common understanding where the former would be expected to sorb more heavy metals than the latter. As the pore size of synthetic zeolite $\mathrm{X}$ is larger than that of synthetic zeolite A, Chang and Shih [38] concluded that size of pores have an important role in the sorption of heavy metals by zeolites. However, only limited studies have been conducted to systematically investigate the effect of pore size on the sorption of heavy metal ions. Additionally, only a portion of heavy metals enter into the pores. Quantifying the contribution of pore structure in total heavy metal uptake may further explain the influence of pore size. However, such studies are rare in the literature possibly due to relative difficulty in undertaking such analysis.

The particulates in stormwater can clog the pores of zeolites. This may recondition/remodel the diffusion of heavy metals into the zeolite framework since it reduces the size of pore openings and channels, which can significantly reduce the effectivness of zeolite in the removal process. Therefore, one of the key considerations in the design of zeolite-based stormwater treatment approaches should be the pore clogging phenomenon.

\subsubsection{Specific Surface Area}

Wang et al. [50] reported that the removal of heavy metals increased with the increase in the specific surface area of zeolite. Similar observations have been reported by other researchers $[33,51]$. This is attributed to the availability of a greater number of sorption sites for heavy metals bonding. However, some studies have reported that the increase in specific surface area does not necessarily increase sorption [52,53].

The specific surface area of porous materials such as zeolite can be divided into the external and internal specific surface areas. The internal specific surface area is governed by the size and distribution of pores. Thus, increasing the external specific surface area by processes such as grinding does not necessarily increase the internal specific surface area [52]. Leyva-Ramos et al. [53] noted that reducing the particle size predominantly increases the external specific surface area more than the internal specific surface area. Therefore, the effect of specific surface area depends on the location of active sites, i.e. whether the majority of the sorption sites are inside the pores or on the external surface. Furthermore, relatively stronger interaction between heavy metal cations and the zeolite framework occur inside the porous structure rather than at the external surfaces [54]. Due to the weak interaction, heavy metal cations bound to external surfaces can be easily desorbed when the conditions of the system such as $\mathrm{pH}$ and temperature are changed. Therefore, increasing the specific surface area sometimes does not necessarily increase the uptake of heavy metals [52,53]. However, it is important to note that the current knowledge on effect of internal and external specific surface areas on the uptake of heavy metals by zeolites is of a theoretical nature. Hence, a systematic study in this regard is needed.

In addition to the clogging the pores, particles in stormwater can also cover the surface of zeolite and thereby reduce the availability of binding sites for heavy metals. Thus, a system design for stormwater treatment could be one in which a hybridisation of different zeolites and other pollutant removal agents are combined. Such a system could be designed such that removal is progressive and is conducted in stages through a series of purpose-built reactors that are designed to provide different binding capability to the stormwater passing through them.

\subsection{Effect of Experimental Conditions}

\subsection{1. pH}

$\mathrm{pH}$ is used as an indirect measurement of the concentration of $\mathrm{H}_{3} \mathrm{O}^{+}$ions in solution. It is one of the crucial parameters in the sorption of heavy metals by zeolites. $\mathrm{pH}$ of stormwater is typically in the range of 6.5 - 7.7 [46]. However, it is possible to have stormwater with lower $\mathrm{pH}$, especially if it flows over very acidic soils or during acid rain. At low $\mathrm{pH}, \mathrm{H}_{3} \mathrm{O}^{+}$can effectively compete with heavy metal cations for sorption sites of zeolites. As a result, the sorption of heavy metals can be reduced [55, 56]. Furthermore, the competition of $\mathrm{H}_{3} \mathrm{O}^{+}$can also slow down the rate of heavy metal uptake. For example, Hui et al. [33] noted that complete removal of heavy metal ions occur within 60 minutes at $\mathrm{pH} 4$ whereas it takes 120 minutes at $\mathrm{pH} 3$. This emphasizes that the development of any zeolite-based technique for stormwater treatment needs to select a suitable retention time at optimum $\mathrm{pH}$ for the effective removal of heavy metals. The competition of $\mathrm{H}_{3} \mathrm{O}^{+}$with heavy metal ions for sorption sites depends on several factors such as the concentration and type of heavy metal ions. For instance, heavy metals that are selective to zeolite and present at high concen- 
tration can outcompete $\mathrm{H}_{3} \mathrm{O}^{+}$ions for sorption sites of zeolite.

Typically, the solution becomes more basic after the introduction of zeolites due to the uptake of $\mathrm{H}_{3} \mathrm{O}^{+}$ions from solution by zeolites. This occurs mainly via ion exchange of extra framework cations for $\mathrm{H}_{3} \mathrm{O}^{+}$ions as shown below:

$$
\mathrm{Z}-\mathrm{M}^{+}+2 \mathrm{H}_{2} \mathrm{O} \longleftrightarrow \mathrm{Z}-\mathrm{H}_{3} \mathrm{O}^{+}+\mathrm{M}^{+}+\mathrm{OH}^{-}
$$

In Equation (1), $\mathrm{Z}$ and $\mathrm{M}$ denote zeolite and extra framework cation respectively. Heavy metal hydroxide precipitation can occur if $\mathrm{pH}$ of solution increases above the threshold level of precipitation for a particular metal ion. Ok et al. [57] reported a substantial increase in the sorption of heavy metals at $\mathrm{pH}$ higher than 6 due to the possible precipitation of the metal ions. The hydroxide precipitation of heavy metal ions in the basic region has been reported in several studies [33,52,58,59]. However, hydroxide precipitation can re-dissolve if the $\mathrm{pH}$ of the solution is changed to the acidic region and the metal ion can be released back to solution [55].

Additionally, heavy metals can form various heavy metal complexes depending on the $\mathrm{pH}$ of solution. For example, $\mathrm{Cr}$ ion is predominantly present as $\mathrm{Cr}\left[(\mathrm{OH})_{2}\right]^{+}$ at $\mathrm{pH} 7$ and as $\mathrm{Cr}\left[(\mathrm{OH})_{4}\right]^{-}$at $\mathrm{pH} 10$ [60]. In general, zeolites have a very little affinity to anionic complexes [61] due to their negative framework structure. Therefore, sorption of a particular heavy metal can be reduced if $\mathrm{pH}$ of solution is favourable to form anionic heavy metal complexes.

Apart from affecting the characteristics of heavy metal ions and their sorption, $\mathrm{pH}$ can also affect the structure of zeolites. Aluminosilicate structure is vulnerable to strong basic and acidic environments. Strong bases can lead to desilication, whereas strong acids can break Al atoms. Zeolite structure can be destroyed at extreme $\mathrm{pH}$ values, which in turn can reduce sorption $[40,43]$. Since zeolite is capable of changing the $\mathrm{pH}$ of the solution, there is a possibility for these processes to occur during the treatment of polluted water. Dealumination is of particular concern due to potential health effects to humans. Australian drinking guidelines set $0.1 \mathrm{mg} / \mathrm{L}$ as the maximum allowable limit of $\mathrm{Al}$ [62]. However, this limit is not based on health consideration due to the lack of data to set a health-based guideline. Hence, it has been highly recommended to keep the $\mathrm{Al}$ concentration as low as possible if the treated stormwater is intended to be used for potable purposes. This emphasises the importance of a detailed investigation of the dealumination processes of zeolite when introduced to the polluted stormwater.

\subsubsection{Temperature}

Temperature of solution influences the heavy metal sorp- tion mainly by enhancing the diffusion of hydrated heavy metal ions [63]. Energy of heavy metal ionic complex in solution increases with increasing temperature. As a result, hydrated heavy metal ions strip off some of the water molecules from their hydrated complexes leading to the reduction of ionic size [64]. This facilitates the diffusion of heavy metal cations into the pores and consequently increases sorption since heavy metal ions can access the extra sorption sites available in the pores. Seward et al. [65] reported that increase in temperature from $25^{\circ} \mathrm{C}$ to $300^{\circ} \mathrm{C}$ has only reduced the distance between metal ion and water by approximately $0.005 \mathrm{~nm}$ resulting only in a slight reduction in the size of heavy metal aqua complex. However, the size reduction can have an impact on some heavy metal ion complexes that have only a few water molecules in their complexes. Additionally, studies have reported that increasing the temperature to $60^{\circ} \mathrm{C}$ results in only a slight increase in the sorption of zeolites possibly due to the insignificant impact on size reduction [66-68]. Hence, enhancing sorption by increasing the temperature is not economically attractive as it involves the consumption of energy [66].

In contrast, some studies have observed a significant increase in the sorption of heavy metals with increase in temperature. For example, Curkovic et al. [69] reported that $\mathrm{Pb}$ sorption capacity of zeolite increased from approximately $0.3 \mathrm{mmol} / \mathrm{g}$ at $4^{\circ} \mathrm{C}$ to $0.55 \mathrm{mmol} / \mathrm{g}$ at $70^{\circ} \mathrm{C}$. Similarly, sorption capacity for $\mathrm{Cd}$ increased from 0.13 to $0.28 \mathrm{mmol} / \mathrm{g}$. Malliou et al. [70] also reported that sorption of $\mathrm{Pb}$ and $\mathrm{Cd}$ increased with temperature. Therefore, the effect of temperature appears to be dependent on other physical and chemical factors such as the strength of metal-water complexes and the characteristics of pores. Thus, the knowledge on the contribution of these factors can provide a basis in the selection of an optimum treatment temperature. Furthermore, in realworld application, the energy consumption must also be considered in optimisation, since large volumes of stormwater generally needs to be maintained to the required temperature.

\subsubsection{Zeolite Concentration}

Increasing zeolite concentration increases the amount of available sorption sites. Therefore, in theory, heavy metal sorption must increase with increasing zeolite concentration. In addition, heavy metal sorption rates increase at high zeolite concentration since it reduces the competition between metal ions due to the availability of more sorption sites $[52,66,71,72]$. However, high zeolite concentration increases the $\mathrm{pH}$ of the system, which successively affects the removal of heavy metals as discussed in Subsection 3.2.1. 
Additionally, zeolites, especially Na pretreated species contain extra framework cations, mainly $\mathrm{Na}$ in their structure. Therefore, a high amount of $\mathrm{Na}$ ions can be released to solution due to the exchange with heavy metal and $\mathrm{H}_{3} \mathrm{O}^{+}$ions in solution when a high zeolite concentration is used. Na cannot be removed easily from water and can alter the taste if it exceeds $180 \mathrm{mg} / \mathrm{L}$ [62]. Furthermore, it can have an impact on cardiovascular patients unless the patients control their $\mathrm{Na}$ level by means of dietary intake if the concentration increases above $20 \mathrm{mg} / \mathrm{L}$ [62].

On the other hand, adequate amount of zeolite must be available to ensure the maximum removal of heavy metals. Alvarez-Ayuso et al. [38] used $10 \mathrm{~g} / \mathrm{L}$ as the optimum zeolite concentration purely to obtain the maximum possible removal of heavy metals. $10 \mathrm{~g} / \mathrm{L}$ has been used by many other researchers $[73,74]$ as a standard zeolite concentration. However, this concentration cannot be taken as a general rule since it is also dependent on the initial metal concentration. Zeolite concentration, therefore, needs to be optimised by taking the relevant factors into consideration. For optimisation, the impact of increasing zeolite concentration on sodium concentration in solution needs to be systematically investigated.

Since stormwater is generally present in large volumes, a large amount of zeolite may be required for its treatment. Disposal of large volume of used zeolite can be an operational issue that needs to be addressed. The prospect of re-generating zeolite after use has been widely discussed in research literature $[75,76]$.

\subsubsection{Initial Heavy Metal Concentration}

Research studies report contradictory observations regarding the effect of initial metal concentration in the removal of heavy metals. The following three different sorption behaviours have been reported in the literature when the initial metal concentration is increased:

- decrease in percentage uptake of heavy metal ions [33, $68,77,78]$

- no effect on heavy metal sorption [32]

- increase in sorption capacities of zeolites for up to certain initial metal concentration and then only a slight increase in sorption $[52,73]$.

In a typical experimental study to evaluate the influence of initial metal concentration, zeolite concentration is usually kept constant, meaning the number of available sorption sites is constant. When the initial metal concentration is increased, the sorption sites available for the uptake of metal ions can be inadequate. This may be the possible reason for the first type of observation. As for the second observation, heavy metal ions were completely removed in the concentration range studied. This could have been due to the availability of an abundance of sorption sites in zeolite used in the study. In case of the third observation, zeolite could have been exhausted due to the occupation of active sites by the ions. Thus, a significant increase in heavy metal uptake was not observed. These observations demonstrate the close relationship between the metal concentration and zeolite concentration. Thus, some research studies have used a parameter, zeolite concentration to zeolite dose ratio, to discuss the effect of these inter-dependent parameters [38, 79].

Stormwater also consists of other metal ions such as $\mathrm{Na}^{+}$and $\mathrm{Mg}^{2+}$, which can compete for sorption sites of zeolite along with heavy metals. The effects of the presence of certain other metal ions have been investigated in relatively few studies $[32,80]$. However, depending on the source characteristics, stormwater can contain a range of metal ions that can compete with each other for the available sorption sites. Therefore, knowledge on the chemical composition of stormwater can be the starting point in the development of the zeolite-based heavy metal removal technology.

\section{Conclusions}

Removing heavy metals is a vital step in stormwater reuse due to its toxicity and persistence in the environment. Use of a low cost sorbent such as zeolite can be considered as a viable alternative for the treatment of heavy metals from stormwater. However, there is a need to update the knowledge base on the influence of zeolite properties as well as the physico-chemical system properties on the treatment performance of zeolite in order to develop optimised zeolite-based technique to remove heavy metals. In this context, this review has identified the following recommendations for further research:

- Quantifying the contribution of pore structure in total heavy metal uptake may further explain the influence of pore size. The diffusion of metal ions within the pore structures of zeolite in stormwater needs to be investigated. The pore clogging phenomenon as well as the covering of zeolite surfaces by particulate matter present in stormwater are key considerations to be taken into account in the design of zeolite-based stormwater treatment technology.

- The $\mathrm{pH}$ of the solution can have significant impact on stormwater quality due to the dealumination or desilication of the zeolite structure. Since zeolite is capable of changing the $\mathrm{pH}$ of the solution, the effect of $\mathrm{pH}$ on stormwater quality in the presence of zeolite needs to be studied.

- The optimum zeolite concentration to treat substantial volumes of stormwater and the subsequent disposal of the waste product should be considered as a key op- 
erational and maintenance issue. At the same time, the relationship between the initial metal concentration in stormwater and the zeolite concentration should also be investigated.

- The leaching of aluminium and sodium ions to solution due to exchange with metal ions gives rise to important health concerns that need to be addressed in the use of zeolites to treat polluted stormwater.

\section{Acknowledgements}

The first author gratefully acknowledges the generous postgraduate scholarship provided to him by the Queensland University of Technology for conducting his doctoral research on zeolite sorption properties to treat heavy metals in urban stormwater.

\section{References}

[1] WHO, "Global Water Supply and Sanitation Assessment 2000 Report," World Health Organization, USA, 2000.

[2] WHO, "Progress on Drinking Water and Sanitation: Special Focus on Sanitation," UNICEF, New York and WHO, Geneva, 2008.

[3] S. Begum, M. Rasul and R. J. Brown, "A Comparative Review of Stormwater Treatment and Reuse Techniques with a New Approach: Green Gully," WSEAS Transactions on Environment and Development, Vol. 4, 2008, pp. 1002-1013.

[4] M. Burns and V. Mitchell, "An Evaluation of the Design, Implementation and Operation of 3 Stormwater Reuse Systems across Melbourne," Proceedings of the 13th International Rainwater Catchment Systems Conference, Sydney, Australia, 2007,

[5] B. Hatt, A. Deletic and T. Fletcher, "Stormwater Reuse: Designing Biofiltration Systems for Reliable Treatment," Water Science and Technology, Vol. 55, No. 4, 2007, p. 201. doi:10.2166/wst.2007.110

[6] S. R. Carpenter, N. F. Caraco, D. L. Correll, R. W. Howarth, A. N. Sharpley and V. H. Smith, "Nonpoint Pollution of Surface Waters with Phosphorus and Nitrogen," Ecological Applications, Vol. 8, No. 3, 1998, pp. 559-568. doi:10.1890/1051-0761(1998)008[0559:NPOSWW]2.0.C $\underline{\mathrm{O} ; 2}$

[7] V. A. Tsihrintzis and R. Hamid, "Modeling and Management of Urban Stormwater Runoff Quality: A Review," Water Resources Management, Vol. 11, No. 2, 1997, pp. 136-164. doi:10.1023/A:1007903817943

[8] B. Sun, M. Sato and J. Clements, "Use of a Pulsed High-Voltage Discharge for Removal of Organic Compounds in Aqueous Solution," Journal of Physics D: Applied Physics, Vol. 32, No. 15, 1999, p. 1908. doi:10.1088/0022-3727/32/15/319

[9] C. Tanner, J. Clayton and M. Upsdell, "Effect of Loading Rate and Planting on Treatment of Dairy Farm Wastewaters in Constructed Wetlands-I. Removal of Oxygen De- mand, Suspended Solids and Faecal Coliforms," Water Research, Vol. 29, No. 1, 1995, pp. 17-26. doi:10.1016/0043-1354(94)00139-X

[10] M. Tomaszewska and S. Mozia, "Removal of Organic Matter from Water by PAC/UF System," Water Research, Vol. 36, No. 16, 2002, pp. 4137-4143. doi:10.1016/S0043-1354(02)00122-7

[11] B. Tryba, A. Morawski and M. Inagaki, "Application of Tio2-Mounted Activated Carbon to the Removal of Phenol from Water," Applied Catalysis B: Environmental, Vol. 41, No. 4, 2003, pp. 427-433. doi:10.1016/S0926-3373(02)00173-X

[12] J. Vymazal, "Removal of Nutrients in Various Types of Constructed Wetlands," Science of the Total Environment, Vol. 380, No. 1-3, 2007, pp. 48-65. doi:10.1016/j.scitotenv.2006.09.014

[13] Z. Xie, "Electrochemical Wastewater Treatment for Denitrification and Toxic Organic Degradation Using Titanium-based Tin Oxide and Ruthenium Oxide Electrodes," Ph.D. Thesis, The University of Hong Kong, Hong Kong, 2006.

[14] D. Dayan and A. J. Paine, "Mechanisms of Chromium Toxicity, Carcinogenicity and Allergenicity: Review of the Literature from 1985 to 2000," Human and Experimental Toxicology, Vol. 20, No. 9, 2001, pp. 439-451. doi:10.1191/096032701682693062

[15] R. M. Jacobs, M. R. S. Fox and M. H. Aldridge, "Changes in Plasma Proteins Associated with the Anemia Produced by Dietary Cadmium in Japanese Quail," Journal of Nutrition, Vol. 99, No. 2, 1969, pp. 119-128.

[16] G. Nicholson, J. Fynn and N. Coroneos, "Cadmium Poisoning in a Crematorium Worker," Anaesthesia and Intensive Care, Vol. 25, No. 2, 1997, pp. 163-165.

[17] N. W. Revis, A. R. Zinsmeister and R. Bull, "Atherosclerosis and Hypertension Induction by Lead and Cadmium Ions: An Effect Prevented by Calcium Ion," Proceedings of the National Academy of Sciences of the United States of America, Vol. 78, No. 10, 1981, pp. 6494-6498. doi: 10.1073/pnas.78.10.6494

[18] S. Satarug and R. M. Michael, "Adverse Health Effects of Chronic Exposure to Low-Level Cadmium in Foodstuffs and Cigarette Smoke," Environmental Health Perspectives, Vol. 112, No. 10, 2004, pp. 1099-1103. doi:10.1289/ehp.6751

[19] P. A. Terry and W. Stone, "Biosorption of Cadmium and Copper Contaminated Water by Scenedesmus Abundans," Chemosphere, Vol. 47, No. 3, 2002, pp. 249-255. doi:10.1016/S0045-6535(01)00303-4

[20] P. Bose, M. Aparna Bose and S. Kumar, "Critical Evaluation of Treatment Strategies Involving Adsorption and Chelation for Wastewater Containing Copper, Zinc and Cyanide," Advances in Environmental Research, Vol. 7, No. 1, 2002, pp. 179-195. doi: 10.1016/S1093-0191(01)00125-3

[21] E. H. Martin, "Effectiveness of an Urban Runoff Detention Pond-Wetlands System," Journal of Environmental Engineering, Vol. 114, No. 4, 1988, pp. 810-827. doi:10.1061/(ASCE)0733-9372(1988)114:4(810) 
[22] J. W. Patterson, H. E. Allen and J. J. Scala, "Carbonate Precipitation for Heavy Metals Pollutants," Journal of the Water Pollution Control Federation, Vol. 49, No. 12, 1977, pp. 2397-2410.

[23] V. Inglezakis and S. Poulopoulos, “Adsorption, Ion Exchange and Catalysis: Design of Operations and Environmental Applications", Elsevier Science Ltd, 2006.

[24] J. E. Baker, S. J. Eisenreich and B. J. Eadie, "Sediment Trap Fluxes and Benthic Recycling of Organic Carbon, Polycyclic Aromatic Hydrocarbons, and Polychlorobiphenyl Congeners in Lake Superior," Environmental Science \& Technology, Vol. 25, No. 3, 1991, pp. 500-509. doi:10.1021/es00015a019

[25] G. M. Ayoub, L. Semerjian, A. Acra, M. El Fadel and B. Koopman, "Heavy Metal Removal by Coagulation with Seawater Liquid Bittern," Journal of Environmental Engineering, Vol. 127, No. 3, 2001, pp. 196-207. doi:10.1061/(ASCE)0733-9372(2001)127:3(196)

[26] T. A. Kurniawan, G. Y. S. Chan, W. H. Lo and S. Babel, "Physico-Chemical Treatment Techniques for Wastewater Laden with Heavy Metals," Chemical Engineering Journal, Vol. 118, No. 1-2, 2006, pp. 83-98. doi:10.1016/j.cej.2006.01.015

[27] S. Babel and T. A. Kurniawan, "Low-Cost Adsorbents for Heavy Metals Uptake from Contaminated Water: A Review," Journal of Hazardous Materials, Vol. 97, No. 1-3, 2003, pp. 219-243. doi:10.1016/S0304-3894(02)00263-7

[28] Kesraoui-Ouki, C. R. Cheeseman and R. Perry, "Natural Zeolite Utilisation in Pollution Control: A Review of Applications to Metals' Effluents," Journal of Chemical Technology \& Biotechnology, Vol. 59, No. 2, 1994, pp. 121-126. doi:10.1002/jctb.280590202

[29] S. Wang and Y. Peng, "Natural Zeolites as Effective Adsorbents in Water and Wastewater Treatment," Chemical Engineering Journal, Vol. 156, No. 1, 2010, pp. 11-24. doi:10.1016/j.cej.2009.10.029

[30] J. Weitkamp, "Zeolites and Catalysis," Solid State Ionics, Vol. 131, No. 1-2, 2000, pp. 175-188. doi:10.1016/S0167-2738(00)00632-9

[31] H. Ghobarkar, O. Schäf, and U. Guth, "Zeolites-from Kitchen to Space," Progress in Solid State Chemistry, Vol. 27, No. 2-4, 1999, pp. 29-73. doi:10.1016/S0079-6786(00)00002-9

[32] S. Ouki and M. Kavannagh, "Performance of Natural Zeolites for the Treatment of Mixed Metal-Contaminated Effluents," Waste Management \& Research, Vol. 15, No. 4, 1997, pp. 383-394. doi: $10.1177 / 0734242 X 9701500406$

[33] K. S. Hui, C. Y. H. Chao and S. C. Kot, "Removal of Mixed Heavy Metal Ions in Wastewater by Zeolite 4A and Residual Products from Recycled Coal Fly Ash," Journal of Hazardous Materials, Vol. 127, No. 1-3, 2005, pp. 89-101. doi:10.1016/j.jhazmat.2005.06.027

[34] B. Biškup and B. Subotic, "Kinetic Analysis of the Exchange Processes between Sodium Ions from Zeolite A and Cadmium, Copper and Nickel Ions from Solutions,"
Separation and Purification Technology, Vol. 37, No. 1, 2004, pp. 17-31. doi:10.1016/S1383-5866(03)00220-X

[35] M. I. Panayotova, "Kinetics and Thermodynamics of Copper Ions Removal from Wastewater by Use of Zeolite," Waste Management, Vol. 21, No. 7, 2001, pp. 671676. doi:10.1016/S0956-053X(00)00115-X

[36] W. Mozgawa and T. Bajda, "Spectroscopic Study of Heavy Metals Sorption on Clinoptilolite," Physics and Chemistry of Minerals, Vol. 31, No. 10, 2005, pp. 706713. doi:10.1007/s00269-004-0433-8

[37] V. J. Inglezakis, M. D. Loizidou and H. P. Grigoropoulou, "Equilibrium and Kinetic Ion Exchange Studies of $\mathrm{Pb}^{2+}$, $\mathrm{Cr}^{3+}, \mathrm{Fe}^{3+}$ and $\mathrm{Cu}^{2+}$ on Natural Clinoptilolite," Water Research, Vol. 36, No. 11, 2002, pp. 2784-2792. doi:10.1016/S0043-1354(01)00504-8

[38] E. Álvarez-Ayuso, A. García-Sánchez and X. Querol, "Purification of Metal Electroplating Waste Waters Using Zeolites," Water Research, Vol. 37, No. 20, 2003, pp. 4855-4862. doi:10.1016/j.watres.2003.08.009

[39] V. K. Jha, M. Nagae, M. Matsuda and M. Miyake, “Zeolite Formation from Coal Fly Ash and Heavy Metal Ion Removal Characteristics Of thus-Obtained Zeolite X in Multi-Metal Systems," Journal of Environmental Management, Vol. 90, No. 8, 2009, pp. 2507-2514. doi:10.1016/j.jenvman.2009.01.009

[40] T. Mishra and S. K. Tiwari, "Studies on Sorption Properties of Zeolite Derived from Indian Fly Ash," Journal of Hazardous Materials, Vol. 137, No. 1, 2006, pp. 299-303. doi:10.1016/j.jhazmat.2006.02.004

[41] H.-L. Chang and W.-H. Shih, "Synthesis of Zeolites A and X from Fly Ashes and Their Ion-Exchange Behavior with Cobalt Ions," Industrial \& Engineering Chemistry Research, Vol. 39, No. 11, 2000, pp. 4185-4191. doi:10.1021/ie990860s

[42] H. Leinonen and J. Lehto, "Purification of Metal Finishing Waste Waters with Zeolites and Activated Carbons," Waste Management Research, Vol. 19, No. 1, 2001, pp. 45-57. doi:10.1177/0734242X0101900106

[43] G. Purna Chandra Rao, S. Satyaveni, A. Ramesh, K. Seshaiah, K. S. N. Murthy and N. V. Choudary, "Sorption of Cadmium and Zinc from Aqueous Solutions by Zeolite 4a, Zeolite 13x and Bentonite," Journal of Environmental Management, Vol. 81, No. 3, 2006, pp. 265-272. doi:10.1016/j.jenvman.2005.11.003

[44] J. Groen, L. Peffer, J. Moulijn and J. Pérez-Ramírez, “On the Introduction of Intracrystalline Mesoporosity in Zeolites upon Desilication in Alkaline Medium," Microporous and Mesoporous Materials, Vol. 69, No. 1-2, 2004, pp. 29-34. doi:10.1016/j.micromeso.2004.01.002

[45] K.-H. Lee and B.-H. Ha, "Characterization of Mordenites Treated by $\mathrm{HCl} / \mathrm{Steam}$ or HF," Microporous and Mesoporous Materials, Vol. 23, No. 3-4, 1998, pp. 211219. doi:10.1016/S1387-1811(98)00118-8

[46] L. Herngren, A. Goonetilleke and G. A. Ayoko, "Understanding Heavy Metal and Suspended Solids Relationships in Urban Stormwater Using Simulated Rainfall," Journal of Environmental Management, Vol. 76, No. 2, 2005, pp. 149-158. doi:10.1016/i.jenvman.2005.01.013 
[47] IZASC (International Zeolite Association Structure Commission), Accessed on 3 April 2009. http://izasc.ethz.ch/fmi/xsl/IZA-SC/ ft.xs1

[48] E. R. Nightingale, "Phenomenological Theory of Ion Solvation. Effective Radii of Hydrated Ions," The Journal of Physical Chemistry, Vol. 63, No. 9, 1959, pp. 13811387. doi:10.1021/j150579a011

[49] M. El-Kamash, A. A. Zaki and M. A. El Geleel, "Modeling Batch Kinetics and Thermodynamics of Zinc and Cadmium Ions Removal from Waste Solutions Using Synthetic Zeolite A," Journal of Hazardous Materials, Vol. 127, No. 1-3, 2005, pp. 211-220. doi:10.1016/j.jhazmat.2005.07.021

[50] C. Wang, J. Li, X. Sun and L. Wang, "Evaluation of Zeolites Synthesized from Fly Ash as Potential Adsorbents for Wastewater Containing Heavy Metals," Journal of Environmental Sciences, Vol. 21, No. 1, 2009, pp. 127-136. doi:10.1016/S1001-0742(09)60022-X

[51] P. Wu and Y.-S. Zhou, "Simultaneous Removal of Coexistent Heavy Metals from Simulated Urban Stormwater Using Four Sorbents: A Porous Iron Sorbent and Its Mixtures with Zeolite and Crystal Gravel," Journal of Hazardous Materials, Vol. 168, No. 2-3, 2009, pp. 674680. doi:10.1016/j.jhazmat.2009.02.093

[52] H. Oren and A. Kaya, "Factors Affecting Adsorption Characteristics of $\mathrm{Zn}^{2+}$ on Two Natural Zeolites," Journal of Hazardous Materials, Vol. 131, No. 1-3, 2006, pp. 59-65. doi:10.1016/j.jhazmat.2005.09.027

[53] R. Leyva-Ramos and G. Aguilar-Armenta, L. V. Gonzalez-Gutierrez, R. M. Guerrero-Coronado, and J. Mendoza-Barron, "Ammonia Exchange on Clinoptilolite from Mineral Deposits Located in Mexico," Journal of Chemical Technology \& Biotechnology, Vol. 79, No. 6, 2004, pp. 651-657. doi:10.1002/jctb.1035

[54] A. H. Ali and R. El-Bishtawi, "Removal of Lead and Nickel Ions Using Zeolite Tuff," Journal of Chemical Technology \& Biotechnology, Vol. 69, No. 1, 1997, pp. 27-34. doi:10.1002/(SICI)1097-4660(199705)69:1<27::AID-JC TB682>3.0.CO;2-J

[55] V. J. Inglezakis, M. D. Loizidou and H. P. Grigoropoulou, "Ion Exchange of $\mathrm{Pb}^{2+}, \mathrm{Cu}^{2+}, \mathrm{Fe}^{3+}$, and $\mathrm{Cr}^{3+}$ on Natural Clinoptilolite: Selectivity Determination and Influence of Acidity on Metal Uptake," Journal of Colloid and Interface Science, Vol. 261, No. 1, 2003, pp. 49-54. doi:10.1016/S0021-9797(02)00244-8

[56] T. Motsi, N. A. Rowson and M. J. H. Simmons, "Adsorption of Heavy Metals from Acid Mine Drainage by Natural Zeolite," International Journal of Mineral Processing, Vol. 92, No. 1-2, 2009, pp. 42-48. doi:10.1016/i.minpro.2009.02.005

[57] Y. S. Ok, J. E. Yang, Y. S. Zhang, S. J. Kim and D. Y. Chung, "Heavy Metal Adsorption by a Formulated Zeolite-Portland Cement Mixture," Journal of Hazardous Materials, Vol. 147, No. 1-2, 2007, pp. 91-96. doi:10.1016/j.jhazmat.2006.12.046

[58] M. Wark, W. Lutz, G. Schulz-Ekloff and A. Dyer, "Quantitative Monitoring of Side Products During High
Loading of Zeolites by Heavy Metals Via pH Measurements," Zeolites, Vol. 13, No. 8, 1993, pp. 658-62. doi:10.1016/0144-2449(93)90139-T

[59] S. K. Pitcher, R. C. T. Slade and N. I. Ward, "Heavy Metal Removal from Motorway Stormwater Using Zeolites," Science of The Total Environment, Vol. 334-335, 2004, pp. 161-166. doi:10.1016/j.scitotenv.2004.04.035

[60] M. Vaca Mier, R. López Callejas, R. Gehr, B. E. Jiménez Cisneros and P. J. J. Alvarez, "Heavy Metal Removal with Mexican Clinoptilolite: Multi-Component Ionic Exchange," Water Research, Vol. 35, No. 2, 2001, pp. 373378. doi:10.1016/S0043-1354(00)00270-0

[61] G. M. Haggerty and R. S. Bowman, "Sorption of Chromate and Other Inorganic Anions by Organo-Zeolite," Environmental Science \& Technology, Vol. 28, No. 3, 1994, pp. 452-458. doi:10.1021/es00052a017

[62] NHMRC (National Health and Medical Research Council), “Australian Drinking Water Guidelines", 2004.

[63] V. J. Inglezakis, M. M. Loizidou and H. P. Grigoropoulou, "Ion Exchange Studies on Natural and Modified Zeolites and the Concept of Exchange Site Accessibility," Journal of Colloid and Interface Science, Vol. 275, No. 2, 2004, pp. 570-576. doi:10.1016/j.jcis.2004.02.070

[64] M. Barros, P. A. Arroyo, E. F. Sousa-Aguiar and C. R. G. Tavares, "Thermodynamics of the Exchange Processes between $\mathrm{K}^{+}, \mathrm{Ca}^{2+}$ and $\mathrm{Cr}^{3+}$ in Zeolite $\mathrm{NaA}$," Adsorption, Vol. 10, No. 3, 2004, pp. 227-235. doi:10.1023/B:ADSO.0000046359.58855.9f

[65] T. M. Seward, C. M. B. Henderson, J. M. Charnock and T. Driesner, "An EXAFS Study of Solvation and Ion Pairing in Aqueous Strontium Solutions to $300^{\circ} \mathrm{C}$," Geochimica et Cosmochimica Acta, Vol. 63, No. 16, 1999, pp. 2409-2418. doi:10.1016/S0016-7037(99)00200-8

[66] A. Ismail, R. M. Mohamed, I. A. Ibrahim, G. Kini and B. Koopman, "Synthesis, Optimization and Characterization of Zeolite A and Its Ion-Exchange Properties," Colloids and Surfaces A: Physicochemical and Engineering Aspects, Vol. 366, No. 1-3, 2010, pp. 80-87. doi:10.1016/i.colsurfa.2010.05.023

[67] M. A. Stylianou, M. P. Hadjiconstantinou, V. J. Inglezakis, K. G. Moustakas and M. D. Loizidou, "Use of Natural Clinoptilolite for the Removal of Lead, Copper and Zinc in Fixed Bed Column," Journal of Hazardous Materials, Vol. 143, No. 1-2, 2007, pp. 575-581. doi:10.1016/j.jhazmat.2006.09.096

[68] S. Wang, M. Soudi, L. Li and Z. H. Zhu, "Coal Ash Conversion into Effective Adsorbents for Removal of Heavy Metals and Dyes from Wastewater," Journal of Hazardous Materials, Vol. 133, No. 1-3, 2006, pp. 243251. doi:10.1016/j.jhazmat.2005.10.034

[69] L. Curkovic, S. Cerjan-Stefanovic and T. Filipan, "Metal Ion Exchange by Natural and Modified Zeolites," Water Research, Vol. 31, No. 6, 1997, pp. 1379-1382. doi:10.1016/S0043-1354(96)00411-3

[70] E. Malliou, M. Loizidou and N. Spyrellis, "Uptake of Lead and Cadmium by Clinoptilolite," Science of the Total Environment, Vol. 149, No. 3, 1994, pp. 139-144. doi:10.1016/0048-9697(94)90174-0 
[71] R. Apiratikul and P. Pavasant, "Sorption of $\mathrm{Cu}^{2+}, \mathrm{Cd}^{2+}$, and $\mathrm{Pb}^{2+}$ Using Modified Zeolite from Coal Fly Ash," Chemical Engineering Journal, Vol. 144, No. 2, 2008, pp. 245-258. doi:10.1016/j.cej.2008.01.038

[72] T. S. Jamil, H. S. Ibrahim, I. H. Abd El-Maksoud and S. T. El-Wakeel, "Application of Zeolite Prepared from Egyptian Kaolin for Removal of Heavy Metals: I. Optimum Conditions," Desalination, Vol. 258, No. 1-3, 2010, pp. 34-40. doi:10.1016/j.desal.2010.03.052

[73] S. Kocaoba, Y. Orhan and T. Akyuz, "Kinetics and Equilibrium Studies of Heavy Metal Ions Removal by Use of Natural Zeolite," Desalination, Vol. 214, No. 1-3, 2007, pp. 1-10. doi:10.1016/j.desal.2006.09.023

[74] A. García-Sánchez, A. Alastuey, and X. Querol, "Heavy Metal Adsorption by Different Minerals: Application to the Remediation of Polluted Soils," The Science of the Total Environment, Vol. 242, No. 1-3, 1999, pp. 179-188. doi:10.1016/S0048-9697(99)00383-6

[75] G. Blanchard, M. Maunaye and G. Martin, "Removal of Heavy Metals from Waters by Means of Natural Zeolites," Water Research, Vol. 18, No. 12, 1984, pp. 15011507. doi:10.1016/0043-1354(84)90124-6

[76] E. Katsou, S. Malamis, M. Tzanoudaki, K. J. Haralam- bous and M. Loizidou, "Regeneration of Natural Zeolite Polluted by Lead and Zinc in Wastewater Treatment Systems," Journal of Hazardous Materials, Vol. 189, No. 3, 2011, pp. 773-786. doi:10.1016/j.jhazmat.2010.12.061

[77] E. Erdem, N. Karapinar and R. Donat, "The Removal of Heavy Metal Cations by Natural Zeolites," Journal of Colloid and Interface Science, Vol. 280, No. 2, 2004, pp. 309-314. doi:10.1016/j.jcis.2004.08.028

[78] H. S. Ibrahim, T. S. Jamil and E. Z. Hegazy, “Application of Zeolite Prepared from Egyptian Kaolin for the Removal of Heavy Metals: II. Isotherm Models," Journal of Hazardous Materials, Vol. 182, No. 1-3, 2010, pp. 842-847. doi:10.1016/j.jhazmat.2010.06.118

[79] S. Ahmed, S. Chughtai and M. A. Keane, "The Removal of Cadmium and Lead from Aqueous Solution by Ion Exchange with Na-Y Zeolite," Separation and Purification Technology, Vol. 13, No. 1, 1998, pp. 57-64. doi:10.1016/S1383-5866(97)00063-4

[80] H. Baker, A. Massadeh and H. Younes, "Natural Jordanian Zeolite: Removal of Heavy Metal Ions from Water Samples Using Column and Batch Methods," Environmental Monitoring and Assessment, Vol. 157, No. 1, 2009, pp. 319-330. doi:10.1007/s10661-008-0537-6 